\title{
HANTU DI TENGAH KERAMAIAN KOTA BANJARMASIN
}

\author{
Nasrullah \\ Universitas Lambung Mangkurat, Banjarmasin \\ nasrullah@ulm.ac.id
}

\begin{abstract}
Ghosts are considered irrational so that they are shunned by society even from scientific studies. Even though in daily practice, ghosts are talked about, discussed, and become a matter of public anxiety. Geertz sees this phenomenon as common sense, or as something that is general knowledge but not rigorously studied. Ghosts initially occupied a haunted area, quiet, isolated, but at this time the location of ghosts transformed into cities. Therefore, this research needs to be emphasized not a ghost as a subject but related to knowledge, belief, understanding or even the testimony of someone against ghosts. The researcher uses the analysis of Levi-Strauss structuralism on phantom phenomena which is considered a myth, because ghosts can do and become anything. In this way, researchers find the rational things bebind this irrational phenomenon, namely the existence of a social construction called bagaduhan, and the existence of ghosts in the human imagination is none other than the existence of common sense and myth that continues to develop.
\end{abstract}

Keywords: Ghost, Rational, Common Sense, Myth.

Abstrak: Hantu dianggap sesuatu yang irasional sehingga dijaubi oleh masyarakat bahkan dari kajian ilmiah. Padahal dalam praktek seharihari, hantu dibicarakan, diperbincangkan, dan menjadi bahan kegelisaban masyarakat. Geertz melibat fenomena ini sebagai nalar awam (common sense), atau sebagai sesuatu yang menjadi pengetabuan umum tetapi tidake dikaji secara kokoh. Hantu pada awalnya menempati daerah angker, sepi, terpencil, tetapi pada saat ini lokasi hantu bertransformasi ke kota. Oleh karena itu, penelitian ini perlu dipertegas bukan bantu sebagai subyek. tetapi berkaitan pengetabuan, kepercayaan, pemahaman atau babkan kesaksian seseorang terhadap bantu. Peneliti menggunakan analisis strukturalisme Levi-Strauss terhadap fenomena hantu yang dianggap 
sebagai suatu mitos, sebab hantu dapat berbuat dan menjadi apa saja. Dengan cara demikian, peneliti menemukan hal-hal rasional di balik fenomena irasional ini yakni adanya konstruksi sosial yang disebut bagaduhan, serta keberadaan hantu dalam imajinasi manusia tidak lain karena adanya nalar awam dan mitos yang terus berkembang

Kata kunci: Hantu, Rasional, Nalar Awam, Mitos.

\section{Pendahuluan}

Tahun 2016, masyarakat Kalimantan Selatan digegerkan dengan berita kemunculan hantu yang tentu saja menimbulkan ketakutan, penasaran dan juga menjadi aneh karena di zaman sekarang hal seperti itu masih dipercayai keberadaanya. Cerita pertama, berasal dari Zulfaisal Putera seorang Pegawai Negeri Sipil (PNS) menampilkan foto hantu di jejaring sosial atau facebook. Awalnya, Zulfaisal hadir dalam pertemuan di rumah dinas gubernur Kalimantan dan saat itu ia mengabadikan momen pertemuan melalui kamera pada smart-phone. Rupanya hasil tangkapan kamera tidak hanya memperlihatkan orang-orang yang dikenal di ruangan tersebut, melainkan ada sosok berpakaian putih yang berambut panjang melintas di belakang orang-orang tersebut. Ia pun memposting foto itu di media sosial dan kemudian ramai diperbincangkan oleh para pengguna media sosial hingga diberitakan pada harian Banjarmasin Post dengan judul berita "Penampakan Sosok Putih di Kediaman Gubernur Kalsel Jadi Perbincangan Netizen".

Penampakan bayangan putih yang muncul di belakang Gubernur Kalsel ketika rapat di kediaman, Ruang Astakona, memunculkan banyak kejadian lainnya. Staf KPU Kalsel, Johnson Marzuki, dalam komentar postingan akun budayawan, Zulfaisal Putera ikut bicara mengenai kejadian lain di Rumah Banjar tersebut. Sosok bayangan putih juga pernah tertangkap kamera ketika audiensi gubernur dengan rombongan perwakilan pengacara. ${ }^{1}$

${ }^{1}$ Anonim. Penampakekan Sosok Putib di Kediaman Gubernur Kalsel Jadi Perbincangan Netizen. (Banjarmasin: Banjarmasin Post. 2016, Juli 15). Diakses pada Juni 2017, dari Tribunenews.com: http://banjarmasin.tribunnews.com/2016/07/19/penampakan-sosokputih-di-kediaman-gubernur-kalsel-jadi-perbincangan-netizen?page=all 
Cerita tentang hantu rupanya tidak hanya di rumah dinas Gubernur saja, pada tahun 2017 masyarakat Kalimantan Selatan mengalami kehebohan akan cerita hantu lagi. Cerita kedua, adalah kemunculan hantu kuyang yang menghebohkan masyarakat Awayan, Kabupaten Balangan, sebagaimana pemberitaan Banjarmasin Post online Geger, Manusia Penghisap Darah 'Kuyang' Muncul di Awayan" (9/1). Dari hasil informasi yang diterimanya beberapa warga mengaku melihat dan menemui langsung sosok tersebut. "Salah satu warga saya yang mengaku melihat adalah Tina, kala itu malam hari suaminya keluar rumah pergi ke pameran, lalu ia mendengar bunyi kerincing-kerincing seperti bunyi suara gelang, dikira suaminya yang datang ternyata sosok hitam berambut panjang menutupi muka muncul dihadapannya," ceritanya. ${ }^{2}$

Selama beberapa hari, berita kuyang terus diterima warga dan diekspos oleh media massa secara on-line. Fenomena kemunculan hantu di masyarakat seperti dua kasus di atas layak mendapat perhatian dalam kajian antropologis, bukan pada hantu itu sendiri melainkan pada pengetahuan dan pemahaman masyarakat terhadap hantu. Hal ini karena berada di luar batas akal manusia, ada keberadaan makhluk lain yang tidak dapat dikuasai manusia secara biasa dan karena itu dunia gaib pada dasarnya ditakuti manusia ${ }^{3}$. Makhluk lain itu, menurut Koentjaringrat termasuk sistem keyakinan yang terdiri dari dewadewa yang baik atau jahat, makhluk-makhluk halus, dan kekuatan sakti yang bermanfaat bagi manusia maupun dapat membawa bencana.

Hantu dalam artikel ini mengacu pada pada istilah umum dalam masyarakat Banjar mengenai makhluk halus dalam jenis apapun dalam hal ini termasuk Kuyang yang dihebohkan masyarakat Awayan. Menurut Daud, wanita kuyangan, karena

\footnotetext{
${ }^{2}$ Anonim. Geger Manusia Penghisap Darah Kuyang Muncul di Awayan (Banjarmasin: Banjarmasin Post. 2017, Januari 1). Diakses tanggal 18 Juni 2017, dari Tribunenews.com: http://banjarmasin.tribunnews.com/2017/01/09/geger-manusiapenghisap-darah-kuyang-muncul-di-awayan?page $=$ all 2005). 203

${ }^{3}$ Koentjaraningrat, Pengantar ilmu Antropologi (Jakarta: Rineka Cipta,
} 
konon meminum minyak kuyang, akan menjadi kuyang pada waktu malam, ditakuti akan menghisap habis darah wanita yang waktu melahirkan dan atau bayinya. Agak mirip dengan kuyang adalah bantu beranak juga mengganggu wanita yang melahirkan dan bayinya ${ }^{4}$. Secara sederhana fenomena kuyang ini dapat dilihat dalam sudut pandang etik (pengamat) yakni: pertama, fenomena kuyang menampilkan oposisi biner antara ketaatan (perilaku religius) melawan kejahatan melalui unsur setan. Kehadiran tokoh masyarakat, tokoh agama, untuk mengajak masyarakat lebih mendekatkan diri kepada Tuhan dalam beribadah seperti shalat dan berzikir adalah solusi tepat untuk memberikan ketenangan di masyarakat.

Kedua, di balik isu kemunculan kuyang yang menciptakan horor dan teror bagi warga, khususnya kalangan ibu-ibu yang baru melahirkan, tanpa disadari menjadi upaya merekatkan atau mengikat kuat solidaritas warga. Warga mendapatkan subyek sebagai common enemy (musuh bersama) yang harus dihadapi, diusir atau dikalahkan yakni kuyang itu sendiri. Muncullah solidaritas warga melalui jaga malam atau ronda bersama untuk meningkatkan keamanan lingkungan sekitar dari gangguan kuyang. Ide ini kelihatan bersifat lokalitas, tetapi jika dicermati juga digunakan secara global. Misalnya melalui filmfilm Amerika seperti Battleship dan Independence Day adalah menghimpun kekuatan manusia dari berbagai bangsa untuk melawan kekuatan makhluk asing. Ketiga, horor kuyang juga dapat merekatkan relasi warga dengan lingkungan (flora) sekitar. Jika sebelumnya bawang merah, bawang putih hanya digunakan untuk keperluan memasak, bambu kuning untuk keperluan lain, hasil tanaman itu dijadikan sebagai special weapon (senjata khusus) mengusir kuyang.

Keempat, bagian ini yang harus disikapi dengan hati-hati. Kemunculan kuyang dalam kepercayaan masyarakat adalah merupakan hantu dari jelmaan manusia yang mencari tumbal

${ }^{4}$ Alfani Daud, "Islam dan masyarakat Banjar: deskripsi dan analisa kebudayaan Banjar" (PhD Thesis, Institut Agama Islam Negeri Syarif Hidayatullah, 1990). Lihat juga Alfani Daud. Islam dan Masyarakat Banjar: Deskripsi dan Analisa Kebudayaan Banjar. (Jakarta: PT RajaGrafindo Persada. 1997). 
darah perempuan baru melahirkan atau anak kecil untuk keperluan awet muda pengasihan atau pesugihan. Pesan moral ada pada upaya mengembalikan kesadaran bahwa perbuatan yang salah untuk tujuan instan menggunakan minyak kuyang justru akan menjauhkan seseorang dari kebaikan dan hanya membuat dampak buruk bagi diri sendiri maupun masyarakat. Namun yang harus ditekankan pesan moral itu cukup sampai pada introspeksi diri masing-masing untuk selalu menempuh jalan kebaikan sebagaimana diajaran dalam agama. Tidak perlu melakukan pencarian keberadaan tokoh antagonis yang menjelma menjadi kuyang karena hanya akan menimbulkan saling curiga dan fitnah belaka.

Cerita makhluk halus juga ditampilkan dalam kehidupan ulama. Irfan Hamka, putera Buya Hamka ulama terkenal asal Minangkabau menceritakan bahwa saat mereka menempati sebuah rumah di Jakarta, setiap malam mereka mendengarkan suara langkah kaki seperti menggunakan tongkat. Suara-suara itu dianggap sebagai langkah makhluk halus penjaga penghuni rumah, tetapi juga ada mengganggu sebagian penghuni rumah yang tidak memiliki kepercayaan terhadap dunia gaib. ${ }^{5}$

Jika dirunut, kurun waktu tahun 2016 hingga 2017, fenomena hantu atau sosok makhluk halus ini tidak hanya terjadi di Kalimantan Selatan saja. Sebuah film horor berjudul The Conjuring II pada tahun 2016 sukses mengundang banyak penonton untuk menyaksikan tayang film hantu di bioskop di berbagai penjuruh dunia. Film hantu baik yang diproduksi film barat hingga berbagai film hantu baik versi lokal, sebagaimana di era 80 ada film Pengabdi Setan, Bayi Ajaib, Sondel Bolong, Ratu Pantai Selatan hingga hantu dalam film di masa sekarang Suster Ngesot, Jeruk Purut, Tusuk Jelangkung, Terowongan Kasablanca, dan ratusan film hantu Indonesia tak pernah putus mengisi imajinasi masyarakat. Itulah sebabnya, pembicaraan tentang hantu tak pernah terkikis oleh perkembangan zaman. Selain film, cerita hantu berkembang melalui tulisan di media online yang disebarkan dalam berbagai versi. Salah satu cerita berjudul Hoax or Not Cerita tentang Dosen Gaib di UAD Yogya yang Bikin Merinding sebagaiman dikutip di bawah ini:

5Irfan Hamka. Ayab (Jakarta: Republika. 2016). 
Iya, katanya dosen minta kuliah pukul setengah 6. Setelah semuanya siap di kelas, ada dosen masuk. Ketika semuanya, termasuk dosen, sudah di kelas, dosen itu hanya diam saja. Sama sekali tidak bicara.

Tiba-tiba ketua kelas mendapat SMS dari dosen asli, yang menyebutkan bahwa perkuliahan dibatalkan karena dia berhalangan.

Tentu saja ketua kelas terkejut. Setelah itu, dosen asli meminta ketua kelas memeriksa kaki 'dosen' yang ada di kelas.

Ketua kelas lalu menjatuhkan bolpoinnya, eh ternyata (kaki 'dosen') tergantung, nggak ada kakinya. Kemudian ketua kelas mengirim pesan ke grup Line: 'Sekarang tolong keluar satu per satu, urut dari yang paling belakang dan tanpa teriakan'. Spontan semua melakukan perintah itu. Nah, yang terakhir keluar adalah ketua kelas. Dosen gaib itu mendekatinya sambil mengatakan, 'Kamu sudah tahu saya?'. Seketika ketua kelas menjerit, dan akhirnya UAD diliburkan selama 3 hari. $^{6}$

Terlepas dari berita tersebut setelah ditelusuri kepada pihak Kampus UAD atau Universitas Ahmad Dahlan, Yogyakarta, yang ternyata tidak benar atau hoax, cerita dosen hantu itu memang membuat heboh masyarakat Indonesia apalagi berbagai varian cerita dimunculkan di media cyber. Di Kalimantan Selatan sendiri, sebelum berita hantu Kuyang atau penampakan makhluk putih di rumah kediamana Gubernur, salah satu media massa on-line telah menampilkan ingatan kolektif warga Kalimantan Selatan tentang peristiwa kerusuhan di Mitra Plaza pada tanggal 23 Mei 2007 yang menimbulkan korban jiwa mencapai ribuan orang. Ingatan itu ditautkan dengan cerita horor sebagai berikut:

Sepekan setelah kerusuhan massal terjadi, gedung Mitra Plaza ini sempat dibiarkan gelap dan kosong. Puing-puing sisa kebakaran juga masih berserakan. Suatu malam, saat dirinya berjalan menuju pulang ke rumah, secara tidak sengaja mata tertuju ke salah satu toko yang berada di depan

'Sukma Indah Permana. Cerita Tentang Dosen Gaib di UAD Yogya yang Bikin Merinding (Jakarta: Detik.com. 2016, 24 Oktober). Diakses 18 Juni 2017dari https://news.detik.com/berita/d-3327648/cerita-tentang-dosengaib-di-uad-yogya-yang-bikin-merinding 
gedung Mitra Plaza di lantai dua. Bau hangus seperti daging terbakar langsung menusuk hidungnya, disaat bersamaan muncul sosok manusia tanpa menggenakan baju dengan wajah hitam berjalan menunduk sambil mondar-mandir mencari sesuatu di depan toko yang terbakar.

Kepercayaan terhadap makhluk halus termasuk kajian antropologi sebagaimana paparan di atas khususnya tentang mitos bahwa sesuatu yang nampaknya tidak masuk akal dan bisa menjadi apapun di luar nalar manusia ternyata di balik semua itu ada hal-hal rasional. Perspektif strukturalisme Levi-Strauss menerangkan pada tataran struktur permukaan (surface structure) tampak ketidakteraturan, tetapi pada tataran struktur paling dalam (deep structure) ada pola keteraturan bahkan ada pesan rasional di balik fenomena ketidakteraturan tersebut. ${ }^{8}$ Selain itu, ada dua hal yang menarik terhadap kepercayaan terhadap makhluk halus. Pertama, trend kemunculan makhlus awalnya pada daerah terpencil, menyeramkan, gelap dan sebagainya mulai berubah dengan kemunculannya di tengah keramaian atau tempat publik seperti di kediaman Gubernur. Kedua, cerita tentang rupanya terus bertahan hingga sekarang. Padahal tahun 2016-2017 adalah era media digital atau cyber media yang memiliki efek desakralisasi karena adanya keterbukaan untuk menampilkan sesuatu di media sosial. Pada masa lalu memiliki atau memajang foto perempuan adalah tabu dan juga suatu keistimewaan. Foto seorang perempuan tidak boleh dimiliki sembarang orang, karena dapat dianggap memberikan kesempatan untuk berniat tidak baik seperti guna-guna oleh orang tertentu. Sebaliknya, memiliki foto seorang perempuan menjadi istimewa karena dianggap seorang laki-laki tersebut

${ }^{7}$ Anonim. Menguak Kisah-kisah Horor Kota dari Mitra Plaza hingga Hutan Mistis Gambut (Banjarmasin: Prokalsel. 2016, 22 Februari). Diakses pada tanggal 18 Juni 2017 dari http://kalsel.prokal.co/read/news/1793menguak-kisah-kisah-horor-kota-dari-hantu-mitra-plaza-hingga-hutanmistis-gambut/1

${ }^{8}$ Heddy Shri Ahimsa-Putra. Strukturalisme Levi-Strauss Mitos dan Karya Sastra. (Yogyakarta: Kepel Press. 2006). Lihat juga "Strukturalisme LéviStrauss : mitos dan karya sastra (Book, 2006) [WorldCat.org]," diakses 13 September 2018, https://www.worldcat.org/title/strukturalisme-levi-straussmitos-dan-karya-sastra/oclc/214931893\&referer=brief_results. 
memiliki hubungan khusus dengan sang perempuan. Pun cerita tentang hantu hanya disebarkan dari mulut ke mulut, adapun visualisasi hantu adalah sesuatu yang tidak lazim. Kini, hantu atau makhluk halus tidak hanya diceritakan dari mulut ke mulut tetapi tersebar secara visual. Meskipun demikian, hantu tetap menjadi subyek yang menakutkan, menebarkan horor dan sekaligus membuat masyarakat menjadi tenang.

Oleh karena itu, artikel ini membahas hal yang berbeda yakni tentang keberadaan hantu di kota Banjarmasin karena selama ini hantu selalu diidentikkan dengan tempat angker, seperti kuburan, rumah tua, pohon-pohon besar, kegelapan dan sebagainya. Kaitan dengan hal ini Geertz telah lama mengingatkan bahwa sebagaimana di tanah Jawa.

Sementara kebudayaan Jawa berkembang dan hutan tropis yang lebat berubah menjadi tanah persawahan dan perumahan, makhluk halus mundur ke sisa hutan berantara, puncak-puncak gunung berapi, dan lautan Hindia (di mana Lara Kidul, Ratu Laut Selatan dan barangkali satu-satunya lelembut Jawa yang paling berkuasa menunggu seseorang yang cukup tolol dan keras kepala untuk memakai pakaian hijau di dekat rumahnya buat ditenggelamkan ke dasar samudra).

Catatan Geertz di atas menunjukkan adanya ketidakseimbangan ekologis, sehingga habitat makhluk halus seperti hantu mulai bergeser ke daerah pelosok. Namun, fenomena hantu di kota menjadi penelitian menarik apakah fenomena ini merupakan arus balik mobilitas hantu yang dulunya berada di tempat terpencil dan jauh tetapi kemudian dihadirkan di tengah keramaian. Artikel ini melihat pandangan masyarakat terhadap hantu di keramaian di tengah hiruk pikuk manusia. Dengan demikian, diharapkan mendapatkan gambaran hantu di tengah kecenderungan masyarakat terhadap media sosial atau cyber media. Ada dua persoalan yang akan didiskusikan dalam artikel ini yakni: Pertama, bagaimana hantu atau makhluk halus diakui keberadaannya di tengah ruang publik kota Banjarmasin? Bagaimana menjelaskan fenomena penampakkan hantu tersebut secara antropologis? Kedua pertanyaan tersebut bermuara pada

${ }^{9}$ Clifford Geertz dan Harsya W Bachtiar, Abangan, santri, priyayi dalam masyarakat Jawa (Jakarta: Pustaka Jaya, 1983). 36 
satu tujuan saya yakni ingin menemukan rasionalitas dari fenomena ketidakmasuk-akalnya keberadaan hantu tersebut.

\section{Metode}

Artikel ini menampilkan pendekatan etnografi untuk menghadirkan narasi atau cerita tentang hantu terutama yang berkembang di kota Banjarmasin. Ada dua alasan mendasar dalam memilih lokasi tersebut. Pertama, terdapat wacana tentang hantu yang ada di rumah kediaman gubernur dan berkembang di jejaring sosial serta diberitkan di media online. Kedua, kota Banjarmasin saat ini ini sedang bergerak menjadi smart city (kota pintar) yang terintegrasi oleh jejaring sosial atau internet sehingga memudahkan akses informasi. Selain itu, kota Banjarmasin adalah kota tua yang memiliki tradisi religius yang terus bertahan juga menjadi kota yang konsentrasi pendidikan tinggi ada di kota ini. Dengan demikian, segala hal yang bersifat rasional lebih dominan di kota Banjarmasin, sedangkan cerita tentang hantu merupakan sesuatu yang irasional dan tentunya menarik untuk dibahas.

\section{Teknik Pengumpulan Data}

Data dalam artikel ini dikumpulkan melalui tiga cara atau teknik, yakni: Pertama, peneliti telah terlibat langsung menghadapi orang-orang yang mengalami kerasukan atau kesurupan makhluk halus. Penulis menyamarkan nama-nama orang yang terlibat dalam peristiwa kesurupan. Kejadian ini merupakan sumber data utama etnografi yang menjadi bagian terpenting dari artikel ini. Kedua, wawancara dilakukan kepada Muhammad Rasyid salah satu karyawan bank swasta dan sebelumnya ia juga pernah bekerja di bagian teknologi informasi (IT) di Duta Mall Banjarmasin. Informan tunggal ini dipilih karena saya percaya kebenaran informasi dan terlebih lagi dia menghadapi langsung kejadian berkaitan dengan penampakkan hantu. Agar jawaban informan teruji kebenarannya, saya melakukan triangulasi data dengan teknik pengumpulan data ketiga, yakni kajian literatur baik berupa literatur primer yang lebih didominasi melihat wacana cerita hantu di Banjarmasin 
yang berkembang di dunia maya baik melalui jejaring sosial maupun web tertentu.

\section{Analisa Data}

Untuk menganalisa data, penelitian menggunakan analisis strukturalisme Levi-Strauss, yang mengacu kepada upaya membuat narasi dari pada masing-masing simbol dalam bentuk miteme dan ceriteme. Ceriteme adalah sebuah unit yang mengandung pengertian tertentu yang seperti halnya miteme hanya dapat diketahui makna atau "pengertiannya" setelah ditempatkan dalam hubungan dengan ceriteme-ceriteme yang lain. ${ }^{10}$ Setelah terlihat alur ceriteme pada rangkaian kalimat kemudian dicari miteme pada tingkat kalimat, tentu saja miteme yang memperlihatkan suatu relasi suatu hubungan-hubungan, miteme kemudian disusun secara diakronis dan sinkronis atau mengikuti sumbu sintagmatis pragmatis ${ }^{11}$. Saya menyadari upaya menggunakan analisis ini tidak mudah dilakukan, tetapi setidaknya terdapat alur analisis yang jelas yakni melakukan binari oposisi dan transformasi untuk menemukan struktur.

\section{Memahami Dunia Hantu}

Kajian tentang makhluk halus atau hantu telah banyak dilakukan, seperti Endaswara yang menulis buku berjudul Dunia Hantu Orang Jawa Alam Misteri, Magis dan Fantasi Kejawen. Buku ini menampilkan berbagai jenis hantu Jawa, relasi mausia dengan hantu seperti dalam tindakan kriminal yang mencopet, mengutil serta menampilkan upaya mengusir hantu hingga menggiring wacana hantu secara komersial dan politik. Menurutnya:

Kesuksesan tayangan film Tusuk Jalangkung tahun 2000, telah mengubah image masyarakat bahwa hantu memang enak ditonton. Kendati dalam film itu, hantu telah difantasikan ulang oleh penulis skenario dan sutradara, toh tetap mampu merebut hati masyarakat. Penonton masih gemar menyaksikan keangkeran kuburan, keanehan Jalangkung mampu berbuat gaib, merasa hingar bingar

\footnotetext{
${ }^{10}$ Heddy Shri Ahimsa-Putra, Strukturalisme Lévi-Strauss: Mitos dan Karya Sastra. h.206

${ }^{11}$ Ibid, h.208
} 
kembali ke alam pemikiran purba. Ternyata pikiran-pikiran masa lalu yang penuh daya ilusi, begitu menggoda bagi orang sekarang. ${ }^{12}$

Jauh sebelum buku tersebut ditulis Endraswara, Geertz dalam buku Abangan, Santri, Priyayi dalam Masyarakat Jawa secara khusus dalam bab "Kepercayaan terhadap Makhluk Halus" mengenai mengklasifikasi empat jenis makhlus halus yakni (1) Memedi: Roh yang menakut-nakuti; (2) Lelembut: Roh yang menyebabkan kesurupan; (3) Tuyul: makhluk halus yang karib; dan (4) Demit: Makhluk halus yang menghuni suatu tempat. Di tengah kepercayaan animisme demikian bagi Geertz, selamatan merupakan penegasan dan penguatan kembali tata kebudayaan umum kekuasaannya untuk menghilangkan kekuatan-kekuatan yang mengacau. ${ }^{13}$

Sementara itu, Raddam dalam Religi Urang Bukit menjelaskan keberadaan beberapa jenis makhluk halus yang menguasai suatu tempat dan dapat memberikan manfaat sekaligus mudharat. Makhluk seperti itu antara lain adalah pujut, adalah ilah yang berada di dan memelihara gunung-gunung, hutan, lembah dan tumbuh-tumbuhan yang berada di sekitar kampung halaman dan balai. Jenis lain disebut pidara, roh ini dapat menyusup ke dalam diri seseorang dan akan mengakibatkan yang bersangkutan sakit yang tidak diketahui pasti sebab musababnya. Ada pula kariau, adalah roh yang dapat memerintah dan dapat memberikan manfaat juga mudarat karena dapat menyesatkan perjalanan manusia. ${ }^{14}$

${ }^{12}$ Suwardi Endraswara. Dunia Hantu Orang Jawa Alam Misteri, Magis dan Fantasi Kejawen. (Yogyakarta: Narasi. 2004). Lihat juga "Dunia hantu orang Jawa: alam misteri, magis, dan fantasi kejawen (eBook, 2004) [WorldCat.org]," diakses 13 September 2018, https://www.worldcat.org/title/dunia-hantu-orang-jawa-alam-misterimagis-dan-fantasi-kejawen/oclc/607370649\&referer=brief_results.

${ }^{13}$ Geertz dan Bachtiar, Abangan, santri, priyayi dalam masyarakat Jawa. 36.

${ }^{14}$ Noerid Haloe Raddam. Religi Orang Bukit Suatu Lukisan Struktur dan Fungsi dalam Kebidupan Sosial Ekonomi (Yogyakarta: Yayasan Semesta. 2001). 194-196 Lihat juga Noerid Haloei Radam, "Religi Orang Bukit: Suatu Lukisan Struktur Dan Fungsi Dalam Kehidupan Sosial-Ekonomi" (Universitas Indonesia: 1987). 
Adapun masyarakat Banjar juga mengenal kepercayaan terhadap makhluk halus, misalnya menurut Daud, makhluk halus yang konon kadang-kadang menampakkan diri pada manusia secara umum dinamakan hantu. Dengan demikian kadang-kadang istilah ini berarti juga orang gaib, seperti ungkapan "disembunyikan hantu”, yang hampir selalu diculik orang gaib. Orang-orang memang takut pada hantu asal (arwah) manusia yang telah berbuat kesalahan. ${ }^{15}$

Berbagai kajian pustaka ini menjelaskan dengan tegas bahwa dunia anismisme ada dalam setiap kebudayaan masyarakat dengan cara yang berbeda pula. Namun kebanyakan makhluk halus atau hantu ditampilkan pada tempat yang jauh dari keramaian, mereka terisolasi dan dapat mengganggu manusia karena manusia itu sendiri mengganggu habitat mereka. Ruang kosong dalam kajian terdahulu adalah bagaimana makhluk halus atau hantu dihadirkan di tengah keramaian.

\section{Penampakan Hantu di Ruang Publik}

Anggapan bahwa hantu atau makhluk halus hanya tinggal di hutan, rumah-rumah kosong, di sisi jembatan, atau di dekat kuburan terbantahkan dengan penuturan Muhammad Rasyid, ia menceritakan pengalamannya bekerja di salah satu areal makanan (food court) di Duta Mall. Di tempat itu ternyata terdapat tempat hantu atau makhluk halus melakukan penampakan. Waktu itu sekitar tahun 2011, di Duta Rasa lantai 3 terdapat ruangan lift yang tidak terpakai dan juga sebuah eskalator yang belum difungsikan, di situlah sering terjadi kemunculan hantu tersebut.

Ia mengetahui hal tersebut, melalui penuturan seorang kasir Duta Rasa yang kebetulan memiliki kemampuan melihat dan berkomunikasi dengan makhluk halus bahkan kasir tersebut pernah kerasukan juga. Penunggu tempat itu adalah babinian bungas, (perempuan cantik) berpakaian putih, dan mereka saling bercakap-cakap.

Selain itu, Muhammad Rasyid juga melihat penampakan melalui tangkapan kamera, kebetulan pada waktu itu ia bekerja sebagai teknisi teknologi informatika (IT) pada Duta Rasa. Lokasi

${ }^{15}$ Daud, "Islam dan masyarakat Banjar." 409 
yang ditemukannya penampakan tersebut adalah lantai dua Duta Mall pada kawasan salon dan tempat orang berjualan parfum. Muhammad Rasyid mengetahui hal tersebut karena ia suka memutar ulang rekaman CCTV terutama untuk melihat aktivitas malam hari. Muhammad Rasyid mendapati seorang perempuan berambut panjang sedang duduk di bangku yang biasanya menjadi tempat nongkrong pengunjung Duta Mall. Selain tertangkap kamera, beberapa security menurut Muhammad Rasyid mencurigai pengunjung Duta Rasa bukanlah manusia. Mereka juga berbelanja sebagaimana kebanyakan pengunjung, tetapi ketika mereka duduk di gazebo menikmati makanan, terlihat tatapan mata mereka kosong.

Muhammad Rasyid juga pernah membawa seorang habib $^{16}$ ke Duta Mall karena sebelumnya ada karyawan Texas Chicken mengalami kesurupan. Ia membawa habib tersebut pada pukul 6 pagi, begitu tiba di basement parkiran habib tersebut sudah merasakan begitu banyak hantu menempati tempat itu. Setelah itu, habib memberikan banyu (air yang sudah diberi mantera) kepada karyawan Texas Chicken agar tidak kerasukan makhluk halus. Menurut Muhammad Rasyid, ia menanyakan karyawan pada saat kerasukan, ternyata penuturan makhluk halus bahwa karyawan tersebut melakukan tindakan tidak senonoh yakni berciuman di belakang toko. Selain itu, menurut Muhammad Rasyid di Duta Mall pernah terjadi kerasukan massal sekitar 2012-2013 sekitar 47 orang di Matahari, Hypermart.

Harian Metro Banjar edisi 26 Juni 2012 memberitakan pada halaman pertama, bahwa:

Selain isu kebakaran, informasi yang didapat ada kejadian kesurupan massal di salah satu toko yang ada di mal tersebut. "Aku baru selesai nonton film. Saat akan pulang, tiba-tiba suasana mendadak lebih ramai. Katanya ada kesurupan massal. Karena banyak orang pada memilih keluar mal, aku juga keluar mal," ujar salah seorang pengunjang mal, Ita, warga Pelaihari.

${ }^{16}$ Habib bagi orang Banjar sangat dihormati karena dalam kepercayaan orang Banjar adalah keturunan Nabi Muhammad SAW. Selain itu, Habib dianggap memiliki kelebihan-kelebihan tertentu. 
Nasrullah

Ita mengatakan, kesurupan itu terjadi di tempat karaoke Family One. "Saya lihat tidak banyak, paling satu dua orang saja," ujarnya.

Terjadinya kesurupan massal itu merebak di jejaring sosial twitter. Akun info banjar menginformasikan terjadinya kesurupan massal di Duta Mall.

"New broadcast, Duta Mall ksurupan massal 46 orang pingsan dan eskalator semua mati," demikian bunyi 'kicauan' (a) Banjarinfo di twitter. ${ }^{17}$

Berita lain pada halaman sama di hari Metro Banjar adalah:

Dari lantai 3 Duta Mall terdengar beberapa orang membacakan ayat suci Alquran. Pengajian itu dilakukan untuk mengusir makhluk halus tubuh karyawati salah satu toko di Duta Mall.

Wawan salah seorang manajer di Departemen Store, Duta Mall, mengakui empat karyawannya kesurupan. ${ }^{18}$

Selain di Duta mall, makhluk halus juga terdapat pada bank di mana Muhammad Rasyid bekerja sebagai tenaga teknisi. Menurutnya bank swasta yang identik dengan pemilik dan nasabah kebanyakan orang Tionghoa ini merupakan bekas rumah Tjilik Riwut gubernur pertama Kalimantan Tengah, sekaligus salah seorang pendiri Kalimantan Tengah. Di tempat itu, konon terdapat kursi santai yang ketika renovasi gedung tahun 1989 tidak bisa dipindahkan hingga akhirnya kursi santai tersebut ditimbun oleh bahan bangunan yang tepat berada di bawah lantai bank tersebut. Penampakan hantu tersebut terlihat oleh satpam bank yang berjaga pada malam hari, ia sering mendengar suara seperti anak-anak yang gaduh di lantai atas. Selain itu, hantu tersebut dapat menyerupai temannya, sebab ada dua orang satpam yang berjaga pada malam hari.

Salah seorang satpam beristirahat di musholla, biasanya mereka tidak boleh bergabung pada tempat yang sama untuk istirahat sebab salah seorang harus berjaga. Namun, ia mendapati

${ }^{17}$ Tim. Pengunjung Duta Mall Panike (Banjarmasin: Metro Banjar, 2012. 26 Juni). $1 \& 8$.

${ }^{18}$ Tim. Zainah Meronta-ronta (Banjarmasin: Metro Banjar, 2012, 26 Juni). $1 \& 8$

36 Khazanah, Vol. 16 (1), 2018 
temannya berada di areal yang sama tetapi tidak menyahut ketika dipanggil. Akhirnya satpam tersebut terlelap sejenak dan kemudian ia kembali berjaga bersama temannya dan bertanya kenapa Pak Rahmadi, temannya tersebut ikut ke belakang. Terkejutlah dia setelah mengetahui bahwa Pak Rahmadi tidak pergi ke belakang melainkan ada makhluk halus menyerupai Pak Rahmadi tersebut.

Pada suatu kesempatan Muhammad Rasyid membawa orang bank dari Balikpapan, bagian jaringan bank tersebut yang memiliki kemampuan indigo untuk melihat makhluk halus pada tahun 2016. Muhammad Rasyid juga membawa kepala bagian logistik bank untuk melihat suasana yang tak kasat mata tersebut. Mereka datang setelah shalat magrib, melewati tangga darurat dan menemukan makhluk halus seperti kuntilanak yang bergelantungan di langit-langit rumah. Ada juga sosok lelaki tua berbahasa Banjar berada di ruangan genset. Lelaki itu tidak senang terhadap orang sombong dan sok berani. Lelaki tua itu juga menginginkan agar mereka tidak diganggu terutama sejak magrib karena mereka sudah berbagi aktivitas dengan karyawan dan nasabah bank pada siang hari. Ia pun senang didoakan agar diampuni dosa-dosanya.

\section{Kerasukan Makhluk Halus}

Bagian ini merupakan pengalaman langsung peneliti dengan orang-orang yang mengalami kerasukan (trance) makhluk halus. Dini hari, peneliti mendapat telepon dari seseorang yang tidak dikenal, ia mengatakan Alma (bukan nama sebenarnya), sepupu peneliti diikuti orang. Oleh karena baru bangun tidur, peneliti merasa kebingungan dengan informasi tersebut sebab kalau diikuti orang mengapa teman-temannya yang di antaranya penelpon itu sendiri yang menjaga Alma. Apalagi jumlah mereka lebih banyak, tetapi peneliti baru menyadari bahwa orang yang dimaksud adalah orang halus yang tak kasat mata. Akhirnya saya mendatangi Alma ke rumahnya dan mendapati ia sedang ketakutan. Alma mengatakan ia merasa ada orang halus yang mengikutinya kemana saja, inilah yang membuat Alma menangis tersedu-sedu dan sesekali memanggil ibunya. Di ruang depan rumah, terdapat beberapa orang laki-laki yang merupakan 
mahasiswa ikut menjaga Alma, mereka juga tidak bisa berbuat apa-apa untuk mengobatinya kecuali hanya berjaga-jaga saja.

Rumah Alma dan juga rumah peneliti berada dalam satu komplek dan hanya berjarak dua blok. Tempat kami ini sebenarnya tidak berada dalam kota Banjarmasin, tetapi berada di pinggiran kota dan aktivitas sehari-hari adalah di kota Banjarmasin. Jika peneliti sebagai tenaga pengajar atau dosen di salah satu perguruan tinggi di negeri yang terletak di kawasan Kayu Tangi, Banjarmasin. Begitu pula Alma, ia mahasiswi di perguruan tinggi swasta yang kampusnya juga terletak di kawasan Kayu Tangi, Banjarmasin. Jadi kota Banjarmasin merupakan tempat yang selalu kami kunjungi setiap hari, terkadang harus bolak-balik setiap hari dari rumah menuju kampus.

Alma adalah mahasiswi semester 7 sebuah perguruan tinggi swasta di kota Banjarmasin. Ia aktif dalam kegiatan kemahasiswaan yang sebagai pengurus sanggar teater, sehingga selain kuliah, Alma disibukkan dengan kegiatan teater baik berlatih di dalam kampus maupun berkegiatan di luar kampus. Salah satu di antara kegiatan tersebut ternyata membuat Alma mengalami kerasukan makhluk halus. Menurut Kakaknya, Hamidi, bahwa Alma juga pernah mengalami kerasukan waktu mengikuti kegiatan kelompok teater di Mandiangin, yakni suatu daerah pegunungan di kabupaten Banjar yang sering digunakan untuk kegiatan outdoor.

Selama beberapa jam, atau menjelang fajar menyingsing, saya dan beberapa orang teman Alma terus menunggu hingga Alma tertidur kelelahan. Kami pun meninggalkan Alma yang masih ditunggu oleh beberapa orang mahasiswi yang juga anggota kelompok teater itu. Saya mengira setelah itu Alma akan baik atau sembuh total, artinya tidak diperlukan upaya untuk penanganan lebih lanjut. Ternyata beberapa bulan kemudian, Alma menyatakan keinginannya untuk diobati secara Islami atau menggunakan rukyah. Namun hal tersebut bagi saya bukan sesuatu yang perlu menjadi perhatian, dengan kata lain, saya masih menganggap sesuatu yang tidak serius. Ternyata Alma memang benar-benar melaksanakan niatnya, ketika itu, ia menghubungi ustadz yang akan 
merukyahnya dan ibu Alma pun datang dari kampung untuk melihat kegiatan rukyah tersebut.

Saya diberitahukan pada siang hari sepulang dari kampus, bahwa rukyah akan dilaksanakan nanti malam atau tepatnya setelah magrib. Entah kenapa saya tidak terlalu percaya dengan rukyah tersebut, saya cenderung ingin mengawasi karena khawatir ustadz yang merukyah bertindak tidak senonoh terhadap Alma meskipun ibu Alma sudah ada di rumah. Ringkas cerita, malam pun tiba, saya mendatangi rumah Alma dan sudah ada menunggu pula ibu Alma serta dua orang teman Alma, bernama Delilla dan Ifadah. Delila sosoknya lebih gemuk dan Ifadah badannya hampir sama dengan Alma. Ustadz Agus yang diminta Alma belum juga datang sebagaimana pada kesepakatan waktu, hingga akhirnya ustadz itu datang setelah shalat isya.

Hati saya agak tenang karena ustadz Agus datang dengan membawa istrinya. Sebelum melakukan rukyah, ia meminta Alma duduk di hadapannya, saya ikut memantau tepat di belakang Alma. Tak lama kemudian dua orang teman Alma juga ikut bergabung dan mereka duduk sejajar dengan Alma. Ibu Alma dan istri ustadz Agus duduk di tepi, bersandar di dinding rumah. Jadi Alma dan kawan-kawannya, berada di tengah kami. Ustadz Agus terlebih dahulu menjelaskan, rukyah yang dilakukannya tidak seperti yang terlihat sebagaimana di televisi. Ia menjelaskan, bahwa ruqyah itu merupakan pengobatan yang dilakukan secara Islami menggunakan bacaan-bacaan dari ayat suci al-Quran. Ustadz Agus bertanya pada Alma, selama ini dia bermimpi apa saja. Alma pun menceritakan pernah bermimpi bertemu dan berteman dengan buaya, begitu juga salah seorang temannya menceritakan mimpi yang tak jauh beda dengan dengan Alma.

Mulailah ustadz Agus melakukan ruqyah, ia meminta Alma untuk mendengarkan bacaan dengan duduk menunduk saja. Ustadz Agus mulai membaca beberapa surah pendek, seperti al-Ikhlas, al-Falaq, An-Nas, kemudian beberapa ayat dalam surah al-Baqarah termasuk ayat Kursi. Tidak berapa lama, Alma berteriak-teriak terkadang tertawa terkekeh-kekeh. Kadang meringis kesakitan, ia melawan kadang minta dikeluarkan. Saya yang berada di belakangnya diminta oleh Ustadz Agus 
membacakan ayat Kursi berulang-ulang kali, di samping ustadz itu membaca berbagai ayat suci Quran, Alma terus meraungraung hingga akhirnya ia terkapar lunglai. Alma kemudian dibawa ke dalam kamar tidur oleh ibunya dan tertinggal satu orang temannya bernama Hafidah yang duduk sambil menyembunyikan pandangannya.

Menurut Ustadz Agus, Hafidah yang kelihatannya diam mematung sebenarnya kerasukan dan benar juga ketika ia dibacakan ayat suci, Hafidah meraung-raung dan tertawa melawan. Agaknya kondisi Hafidah lebih parah dari Alma, saya tetap diminta membacakan ayat Kursi, sedangkan sikap ustadz Agus sama seperti memperlakukan Alma membaca berulang kali berbagai ayat-ayat suci. Dari gerakan tanggannya mengesankan bahwa ia sedang mengeluarkan makhluk halus dalam tubuh Hafidah berulang kali. Jika terhadap Alma, ustadz Agus mengeluarkan makhluk halus sebanyak tiga kali, maka terhadap hafidah dilakukannya selama lima kali hingga akhirnya Hafidah terbaring lemah dan tak berdaya. Untungnya satu orang teman Alma yakni Delila tidak ikut kerasukan sehingga yang ditangani hanya dua orang.

Setelah upaya mengeluarkan makhluk halus dilakukan terhadap dua orang itu, ustadz Agus pun memberikan petuah agar makhlus halus tidak lagi berada dalam tubuh mereka. Ia pun meminta Alma dan Hafidah membaca empat surah pendek, yakni Al-Fatihah, al-Ikhlas, An-Nas, dan al-Falaq yang ditiupkan ke tangan dan disapukan ke seluruh tubuh terutama pada saat akan tidur di malam hari. Praktek membacakan surah pendek itu menurut ustadz Agus adalah untuk mengetahui apakah makhluk halus masih berada dalam tubuh mereka dan setelah membaca ayat-ayat itu tidak ada reaksi apa-apa. Kemudian ustadz Agus memberikan bungkusan garam kepada mereka untuk ditaburkan di sekitar rumah dan lagi-lagi untuk menguji keberadaan makhluk halus di dalam tubuh mereka, ustadz Agus meminta Alma dan Hafidah untuk mencicipi sedikit garam ke lidah mereka. Ternyata setelah merasakan garam itu, Alma langsung bereaksi sambil tertawa terkekeh mengejek ustadz Agus, rupanya makhluk itu masih berada dalam tubuh Alma dan ia tidak mau keluar. Pada 
saat bersamaan, Hafidah pun bereaksi dengan tertawa terbahakbahak.

Mereka secara serempak melakukan perlawanan kepada Ustadz Agus. Kami memisahkan keduanya, Alma kembali dibawa masuk ke dalam kamarnya. Ditemani istri dan ibu Alma, ustadz Agus merukyah Alma, sedangkan Hafidah berada di ruang tamu dan saya diminta menunggunya sambil membacakan ayat kursi berulang-ulang kali. Suasana mendadak chaos karena Alma dan Hafidah atau lebih tepatnya makhluk halus di dalam tubuh keduanya ingin berkelahi. Mereka saling mengejek, berteriak, keduanya bersiap untuk menjambak dan diiringi tatapan mata yang tajam. Saya dan ustadz Agus berusaha melerai keduanya. Mata saya bertatapan dengan tajamnya pandangan mata Alma yang tidak pernah saya lihat pada saat Alma dalam kondisi normal. Kini ustadz Agus berusaha merukyah Hafidah sedangkan Alma, saya jaga agar tidak menerjang Hafidah.

Akhirnya Hafidah bisa ditangani dan ia terbaring lemah, saya kemudian diminta menangani Hafidah dengan berulang kali membacakan ayat Kursi. Kini, Alma sedang kesurupan mampu berbahasa Indonesia dengan sangat fasih. Padahal ia adalah gadis berbahasa Bakumpai yang kalau berbahasa Indonesia akan sangat kaku. Dari gesture (gerak tubuh) dan penampilan Alma, agaknya dia kerasukan makhluk halus seperti anak kecil. Ia berteriak dan berjanji ingin keluar asal diantar ke kampus Alma karena menurutnya di tempat itulah ia pertama kali masuk dalam tubuh Alma. Makhluk halus itu bersumpah untuk keluar asal Alma dibawa ke kampus. Akhirnya ustadz Agus berkompromi untuk membawa Alma menggunakan satu buah motor yang ditumpangi bertiga dengan salah seorang teman Alma yang tidak kesurupan.

Memahami Penampakkan Hantu Melalui Konstruksi Sosial, Nalar Awam, dan Mitos

Berdasarkan penyajian data di atas, dapat kita analisa bahwa keberadaan hantu dan konstruksi sosial tidak lah benarbenar sebagai sesuatu yang konkret. Pola penampakan dapat terlihat sebagaimana struktur di bawah ini:

\section{Gambar 1 Binary Oposisi Keberadaan Hantu}


Nasrullah

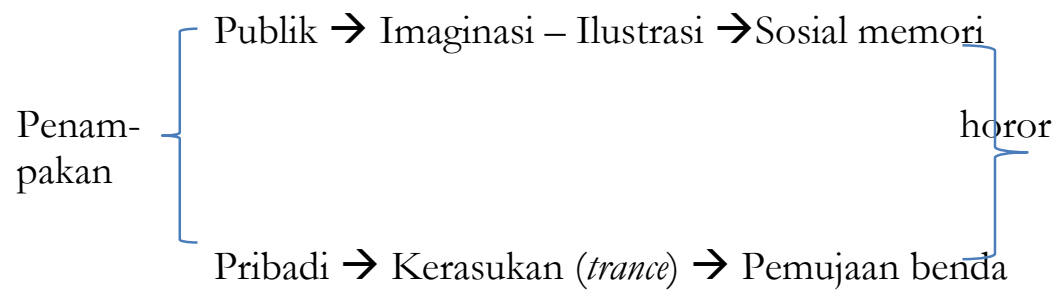

Dari gambar di atas dapat diketahui transformasi kehadiran hantu dari bersifat publik dan bersifat pribadi. Hantu atau makhluk halus tersebut dapat muncul dari berbagai ruang, ketika kemunculannya di ruang publik baik di mall atau di bank dan tempat-tempat lain, hantu tersebut menghadirkan imajinasi atau penampakan dalam berbagai bentuk. Pada umumnya hantu menampilkan imajinasi perempuan berpakaian putih dan berambut panjang, tetapi dapat juga muncul sebagai laki-laki dan anak-anak. Sebagaimana di tanah Jawa, Geertz, membagi makhluk halus yakni memedi (harfiah tukang menakut-nakuti), lelembut (makhluk halus) dan Kepercayaan roh kalangan abangan di Mojokuto bukanlah merupakan bagian dari suatu skema yang konsisten, sistematis, dan terintegrasi, tetapi lebih serupa rangkaian imaji-imaji berlainan, yang konkrit, spesifik, yang dirumuskan secara agak tajam - metafora-metafor visual yang terlepas satu sama lain yang memberi bentuk kepada berbagai penga laman yang kabur dan yang kalau tidak demikian akan tidak dapat dimengerti. ${ }^{19}$

Selain itu, makhluk halus tidak hadir dalam imajinasi tetapi tampil dalam bentuk watak dan tindakan karena ia menyusup ke dalam raga manusia. Media yang digunakan untuk masuk adalah adanya kepercayaan manusia pada benda-benda pusaka yang dikultuskan memiliki kekuatan tertentu. Jadi kedua bagian tersebut merupakan perpaduan faham animisme adanya roh (anima) yang ada dalam suatu benda tertentu dan tempattempat tertentu. Perpaduan tersebut mewujud pada perasaan horor pada diri manusia akan keberadaan makhluk halus atau hantu. Pertanyaan kemudian, mengapa hantu tersebut terus bertahan dalam imajinasi publik maupun private meskipun

${ }^{19}$ Geertz dan Bachtiar, Abangan, santri, priyayi dalam masyarakat Jawa. 
teknologi canggih dan tingkat pendidikan yang semakin tinggi saat sekarang. Bukankah hal tersebut dapat membuat orang semakin berfikir rasional? Untuk menjelaskan hal tersebut dapat dilihat secara konstruksi sosial, dan melalui nalar awam serta mitos.

\section{Bagaduhan sebagai Konstruksi Sosial Pengakuan Keberadaan Hantu}

Hal ini berkaitan dengan hantu selalu berada dalam imajinasi masyarakat karena hadir dalam social memory (kenangan sosial) yang diwariskan secara berkelanjutan bahkan diperkuat adanya fenomena keberadaan hantu hingga memasuki tubuh manusia yang disebut karasukan (trance) salah satunya karena adanya kepercayaan dari sejak masa lalu yang turun temurun berkaitan dengan bagaduban atau memelihara makhluk halus. Kepercayaan masyarakat tentang bagaduban ini adalah apabila tidak dilakukan kegiatan memberi makan atau sesaji kepada makhluk halus maka makhluk halus tersebut akan menyiksa keturunan manusia yang memeliharanya. Agar siksa itu tidak terjadi maka manusia secara rutin, setiap tahun atau waktu tertentu memberikan makan atau sesaji kepada gaduban (peliharaan) tersebut. Acapkali orang menjadi lupa memberikan makan, sehingga apabila ada anggota keluarga yang mengalami sakit, orang akan mengingat-ingat apakah ada gaduhan tidak diberi makan. Maka ada salah seorang anggota keluarga berucap, kurang lebih demikian, "nanti kami memberi makan, asal kalian tidak melakukan siksa terhadap keluarga kami.

Kepercayaan yang ada hingga sekarang terasa dampaknya apabila ada seseorang yang kerasukan, maka salah satu penyebab yang sulit dihilangkan adalah kebiasaan memberikan makan gaduhan tersebut. Harapan agar terjadi simbiosis mutualisme antara gaduhan dan manusia sesungguhnya tidak benar-benar terjadi, malah gaduhan menjadi parasitisme bagi manusia atau keluarga bersangkutan. Gaduban itu sendiri melekat melalui media benda-benda pusaka yang disakralkan seperti senjata yakni keris, tombak, cemeti, jimat, rajah dan sejenisnya. Para perukyah dalam mengobati pasiennya tidak bisa 
sampai tuntas menghilangkan makhluk halus dalam tubuh karena mereka berdiam pada benda-benda yang disakralkan tersebut.

Cerita ustadz Agus bahwa jangankan orang biasa, seorang ustadz atau kiai yang hafal al-Quran pun dapat dimasuki makhluk halus atau kerasukan. Cerita ini berkembang di kalangan sesama perukyah, bahwa ada seorang ustadz pengelola pondok pesantren yang merasakan sakit kepala luar biasa. Ia pun kemudian dirukyah dan ternyata kerasukan jin muslim yang pandai mengaji maka dengan mudah segala bacaan ayat-ayat suci yang dibacakan perukyah diikutinya. Mereka pun agak kesulitan mengobati ustadz tersebut hingga salah seorang menanyakan kepada istri ustadz tentang barang-barang pusaka dimiliki ustadz. Mereka mendapati beberapa bilah keris, pedang, dan lain sebagainya sebagai benda pusaka yang dikultuskan dan kemudian mereka siram dengan bensin untuk dibakar. Setelah benda-benda itu dibakar, maka ustadz itu pun sembuh seketika.

Kadangkala masyarakat tertipu akan jimat atau rajah yang dikira memiliki nilai relijius atau ajaran Islami, ternyata jimat itu sendiri merupakan kamuflase yang di dalamnya justru tempat bersemayam makhluk halus. Untuk itulah, selain benda pusaka atau senjata tajam dikultuskan, jimat, rajah, dan sejenisnya merupakan benda yang di dalamnya terdapat makhlus halus dan sewaktu-waktu dapat mengganggu pemiliknya.

\section{Keberadaan Hantu dalam Nalar Awam dan Mitos}

Sebagaimana telah dijelaskan bahwa artikel ini ini tidak menelaah pada keberadaan hantu atau sebangsa makhluk halus, tetapi berkaitan dengan kepercayaan, faham, atau pengetahuan dan lain-lain yang dimiliki masyarakat terhadap hantu tersebut. Geertz menerangkan berikut ini:

Ada banyak pembicaraan dan perdebatan tentang makhluk halus, dan sementara ada kesepakatan tentang adanya dan pentingnya makhluk adakodrati (supernatural, yang sebagai suatu kelompok disebut bangsa alus), setiap orang nampaknya mempunyai pendapat sendiri mengenai sifatnya yang tepat dan beberapa pengalaman pribadi untuk membuktikannya. ${ }^{20}$

${ }^{20}$ Geertz dan Bachtiar, Abangan, santri, priyayi dalam masyarakat Jawa. 
Geertz menjelaskan hal tersebut dengan sebuah cerita berikut ini yang menunjukkan bagaimana kuatnya kepercayaan seseorang terhadap ilmu hitam:

Katakan seorang anak Zande tersandung tunggul pohon dan terkena infeksi. Anak itu mengatakan bahwa ini akibat ilmu hitam. Evans-Pritchard mengatakan "nonsense", tidak masuk akal; seharusnya kamu lihat jalan. "Sudah lihat jalan," kata anak itu. "Bagaimana tidak dengan banyaknya tunggul di sekitar sini dan kalau saya tidak kena guna-guna pasti saya melihatnya dan tidak akan seperti ini". "Apalagi, semua luka tidak makan waktu berhari-hari untuk sembuh dan menutup kembali sedangkan yang ini membusuk, pasti ada ilmu hitam terlibat di sini." 21

Hal seperti inilah yang barangkali disebut Geertz sebagai nalar awam atau pandangan umum yang dimiliki kebanyakan orang. Begitu pula tentang hantu ini dapat diklasifikasi sebagai nalar awam yang tidak harus dipertentangkan kebenarannya. Cerita hantu meskipun mengikat manusia dengan segala hal berbau horor dan ketakutan tetapi ia sebagaimana dongeng dapat muncul dengan berbagai macam keanehan atas hantu itu dan juga berbagai varian ceritanya sehingga ada di balik jerat ketakutan itu ada kebebasan manusia dalam membuat segala cerita.

Sehingga berbagai kasus kemunculan hantu sebagaimana paparan di atas termasuk berbagai berita yang berkembang tentang hantu, tercermin kebebasan manusia dalam menampilkan rasa ketakutan melalui manifestasi hantu yang muncul dari imajinasi masing-masing. Bahkan tautan narasi demi narasi hantu tersebut berupaya mencari pembenaran yang saling melengkapi dan lama kelamaan narasi tersebut menjadi mitos.

Dongeng merupakan suatu kisah atau ceritera yang lahir dari hasil imajinasi manusia, dari khayalan manusia, walaupun unsur khalayan tersebut berasal dari apa yang ada dalam kehidupan manusia sehari-hari. Dalam dongeng inilah khayalan manusia memperoleh kebebasan mutlak, karena itu tidak ada larangan bagi manusia untuk menciptakan dongeng apa saja. Di

${ }^{21}$ Clifford Geertz, Pengetahuan Lokal Esai-esai Lanjutan Antropologi Interpretatif (Yogyakarta: Merapi, 2003). 101 
situ bisa ditemukan hal-hal yang tidak masuk akal, yang tidak mungkin kita temui dalam kehidupan sehari-hari. ${ }^{22}$.

Dengan demikian, cerita tentang hantu dan makhluk halus atau bukan berkenaan langsung dengan hantu, karena artikel ini tidak bersangkutan dengan hantu sebagai obyek atau subyek melainkan terhadap kepercayaan manusia dapatlah kita lihat sebagai bentuk kajian mitos. Lebih baik kita mengakui bahwa studi tentang mitos membawa kita pada penguatan yang bersifat kontradiktif. Segala hal bisa terjadi dalam mitos. ${ }^{23}$

\section{Penutup}

Sebagai kesimpulan dari penelitian ini sekaligus menjadi jawaban atas pertanyaan penelitian sebagaimana dikemukakan, sebagai berikut:

Pertama, keberadaan hantu atau makhluk halus tidak sebagaimana dibayangkan hadir di tempat sepi, angker, seram dan lain sebagainya. Keberadaannya diakui dari berbagai kejadian yang berasal dari tangkapan visual dan pengalaman orang lain dalam pertemuan dengan hantu. Ada akses tertutup terhadap pertemuan dengan hantu atau makhluk halus tersebut atau tidak semua orang dapat menemuinya karena terbatas pada orang dengan kemampuan tertentu saja. Meskipun sedemikian samarnya keberadaan hantu atau makhluk halus, terlebih tidak semua orang dapat melihat secara langsung - sebagian besar hanya cerita dari mulut ke mulut - tetapi pada kenyataannya semakin tidak pasti kebenaran akan keberadaan hantu atau makhluk halus, semakin tinggi nilai daya tarik horror yang dihasilkan dari cerita tersebut.

Kedua, memahami kehadiran hantu dalam imajinasi masyarakat sekarang ini ternyata tidak mampu dibatasi oleh kecanggihan teknologi dan semakin tingginya tingkat pendidikan. Rasionalitas keberadaan hantu justru menancap pada pondasi konstruksi sosial yang disebut bagaduban sebagai relasi manusia dengan makhluk halus terus dipertahankan saat ini. Konstruksi

Karya Sastra. 77

${ }^{22}$ Heddy Shri Ahimsa-Putra, Strukturalisme Levi-Strauss Mitos dan

23 Claude Levi-Strauss, Antropologi Struktural (Yogyakarta: Kreasi Wacana, 2005). 278

46 Khazanah, Vol. 16 (1), 2018 
sosial inilah yang menyebabkan hantu atau makhluk halus eksis adalah terbangunnya aliansi yang secara sadar atau tidak sadar dibuat oleh manusia itu sendiri. Manusia membangun jembatan kedekatan terhadap makhluk halus dengan kultusnya terhadap benda-benda tertentu sebagai faham animism, atau kekuatan dinamisme yang secara turun temurun diwariskan dari generasi ke generasi. Makhluk halus dalam hal ini diakui sebagai kekuatan tertentu yang dapat mengganggu manusia. Sehingga manusia mesti bergantung kepada kekuatan yang lebih tinggi berdasarkan nilai-nilai (i)rasional, pengalaman transedental dari ajaran agama.

Selain itu terdapat adanya nalar awam, sebagai sesuatu yang terus berkembang hingga menjadi dongeng atau mitos. Ternyata dalam keadaan tersebut, manusia mengalami kebebasan dalam berimajinasi meskipun imajinasi tersebut melahirkan visualitas semu yang meneror dirinya sendiri dalam ketakutan. Akhirnya mengutip pendapat Geertz, manusia telah terperangkap dalam jaring laba-laba yang dipintalnya sendiri.

\section{Daftar Pustaka}

Ahimsa-Putra, H. S. Strukturalisme Levi-Strauss Mitos dan Karya Sastra. Yogyakarta: Kepel Press. 2006.

Anonim. (2016, Juli 15). Banjarmasin Post. Dipetik Juni 18, 2017, dari

Tribunenews.com: http://banjarmasin.tribunnews.com/2016/07/19/pena mpakan-sosok-putih-di-kediaman-gubernur-kalsel-jadiperbincangan-netizen?page $=$ all

Anonim. (2016, Februari 22). ProKalsel. Dipetik Juni 18, 2017, dari Prokal.co: http://kalsel.prokal.co/read/news/1793menguak-kisah-kisah-horor-kota-dari-hantu-mitraplaza-hingga-hutan-mistis-gambut/1

Anonim. (2017, Januari 1). Banjarmasin Post. Dipetik Juni 18, 2017, dari Tribunenews.com: http://banjarmasin.tribunnews.com/2017/01/09/geger -manusia-penghisap-darah-kuyang-muncul-diawayan?page $=$ all 
Nasrullah

Anonim. Kota Banjarmasin dalam Angka 2017. Banjarmasin: BPS Kota Banjarmasin. 2017.

Daud, A. Islam dan Masyarakat Banjar: Deskripsi dan Analisa Kebudayaan Banjar. Jakarta: PT RajaGrafindo Persada. 1997.

Daud, Alfani. "Islam dan masyarakat Banjar: deskripsi dan analisa kebudayaan Banjar." PhD Thesis, Institut Agama Islam Negeri Syarif Hidayatullah, 1990.

Endraswara, S. Dunia Hantu Orang Jawa Alam Misteri, Magis dan Fantasi Kejawen. Yogyakarta: Narasi. 2004.

Geertz, C. Abangan, Santri, Priyayi dalam Masyarakat Jawa. Jakarta: Pustaka Jaya . 1983.

Geertz, C. Pengetahuan Lokal Esai-esai Lanjutan Antropologi Interpretatif. Yogyakarta: Merapi. 2003.

Geertz, Clifford, dan Harsya W Bachtiar. Abangan, santri, priyayi dalam masyarakat Jawa. Jakarta: Pustaka Jaya, 1989.

Hamka, I. Ayah... Jakarta: Republika. 2016.

Koentjaraningrat. Pengantar Ilmu Antropologi. Jakarta: Rineka Cipta. 2005.

Koentjaraningrat. Pengantar ilmu Antropologi. Jakarta: Rineka Cipta, 2009.

Levi-Strauss, C. Antropologi Struktural. Yogyakarta: Kreasi Wacana. 2005.

Permana, S. I. (2016, Oktober 24). Detik. Dipetik Juni 18, 2017, dari Detik.com: https://news.detik.com/berita/d3327648/cerita-tentang-dosen-gaib-di-uad-yogya-yangbikin-merinding

Radam, N. H. Religi Urang Bukit Suatu Lukisan Struktur dan Fungsi dalam Kehidupan Sosial-Ekonomi. Yogyakarta: Yayasan Semesta. 2001.

Radam, Noerid Haloei. "Religi Orang Bukit: Suatu Lukisan Struktur Dan Fungsi Dalam Kehidupan SosialEkonomi." Universitas Indonesia ; 1987.

Spradley, J. Metode Etnografi. Yogyakarta: Tiara Wacana. 1997. tim. (2012, Juni 26). Pengunjung Duta Mall Panik. Metro Banjar, 1-8.

tim. (2012, Juni 26). Zainah Meronta-ronta. Metro Banjar, 1-8. 